\title{
A Odisseia de Chabert: um herói entre dois tempos ${ }^{1}$
}

Tania Leite ${ }^{2}$

Resumo: Este estudo discute a construção, no século XIX, de uma narrativa que retoma o topos clássico do "retorno do herói", com base no romance $O$ coronel Chabert (Le colonel Chabert), de Honoré de Balzac. A obra balzaquiana foi analisada na chave do conceito de aemulatio, buscando perceber as apropriações que o autor faz da poesia épica Odisseia, de Homero.

Palavras-chave: Balzac; O coronel Chabert; Homero; Odisseia; emulação

Abstract: This article discusses a narrative that reclaims the classic topos of the "hero's return", built on the XIX century based on the work of Honore de Balzac, Le colonel Chabert. The balzachian novel is analyzed on the key concept of aemulatio, as to distinguish what the author has appropriated from Homero's epic, Odyssey.

Key words: Balzac; Colonel Chabert; Homer; Odyssey; emulation

\section{A odisseia de Chabert}

Tanto a historiografia literária como a historiografia da cultura têm analisado a relação entre antigos e modernos sob a luz da topologia, ou seja, a partir de topoi literários que, constituídos na antiguidade, são retrabalhados quando da constituição moderna da literatura, no século

\footnotetext{
${ }^{1}$ Este artigo originalmente foi escrito como um capítulo da Monografia apresentada ao Departamento de História da Pontifícia Universidade Católica do Rio de Janeiro, PUC-Rio, para a obtenção do Título de Bacharel em História, 2015.

${ }^{2}$ Atualmente cursando Mestrado no curso de Pós Graduação em História Social da Cultura da Puc-Rio.
} 
XIX, como esfera de reflexão sobre a condição humana e sua historicidade. Nesse sentido, a própria historicidade dos topoi permite acessar o modo como modernos (como Balzac) reapropriaram a tradição.

Temístocles Cesar comenta que, no século XIX, era prática comum, na geração romântica, a conversão de textos de viagem em documentos históricos, resultando em um entrecruzado "entre tempos: o passado, o presente, mas também o descontínuo e a memória; e mundos: o velho e o novo, e, em cada um deles, o antigo e o moderno entre o passado e o presente mundos, que se imiscuem"3.

Nossa intenção nesse artigo, ao fazer uma leitura comparada de uma pequena novela de Balzac intitulada $O$ Coronel Chabert com o poema épico Odisseia, é compreender a forma como Balzac se apropriou de um texto da tradição para contar o seu próprio tempo. Ao mesmo tempo em que se declara observador atento das coisas de seu tempo e lugar, o autor deixa entrever, na tessitura de sua narrativa, ecos da tradição literária.

Para Auerbach, por exemplo, Balzac "considera o presente como história; isto é, o presente é algo que ocorre surgindo da

3 CEZAR, Temístocles. Entre antigos e modernos: a escrita da história em Chateaubriand. Ensaio sobre historiografia e relatos de viagem. Almanack Braziliense, São Paulo, n. 11, p. 26-33, maio 2010. p. 27. Disponível em: <http://www.revistas.usp.br/alb/article/viewFile/11735/13510>. Acesso em: 04 fev. 2017. 
história"4, por isso o escritor, continua o teórico, "não somente localizou os seres cujo destino contava seriamente, na sua moldura histórica e social perfeitamente determinada, como o fazia Stendhal, mas também considerou essa relação como necessária" 5 .

No romance $O$ coronel Chabert, publicado em 1832, estão relatadas as aventuras do personagem Chabert na sua viagem de retorno a Paris, depois de quase vinte anos de ausência - dez anos como herói das guerras napoleônicas e outros dez tentando voltar para casa. Submetido a todo tipo de reveses e sofrimentos, o herói está velho e cansado em seu retorno. Ao chegar, sem documentos que comprovem sua identidade, depara-se com um mundo completamente diferente daquele que deixou: seu palacete fora derrubado e sua esposa, Rosa Chapotel, casada em segundas núpcias, se recusa a recebê-lo.

No poema épico Odisseia $^{6}$, cuja forma escrita é comumente situada entre 700 e 550 a.C. e a autoria atribuída a Homero - não sem controvérsias, tendo em vista a persistente dúvida: terá sido Homero um homem ou apenas um nome? ${ }^{7}-$, Ulisses, após dez anos da longa e

${ }^{4}$ AUERBACH, Eric. Mimesis: a representação da realidade na literatura ocidental. São Paulo: Perspectiva, 2011. p. 430

${ }^{5}$ Ibidem, p. 423.

${ }^{6}$ Carlos Alberto Nunes considera que a Odisseia é um agrupamento de três poemas originais: "A viagem de Telêmaco" (cantos II-IV), "Os relatos na casa de Alcínoo" (cantos V-XII) e "A vingança de Ulisses" (cantos XIV-XXIII). NUNES, Carlos Alberto. Prefácio. In: HOMERO. Odisseia. Ediouro, 2001, p. 14.

7 Trajano Vieira, o tradutor da edição com a qual trabalhamos, refere-se à imensa dificuldade de se afirmar qualquer coisa sobre a vida de Homero. "O mundo antigo não conhece nada de definitivo sobre a vida e a personalidade de Homero”. Cf. Trajano 
sangrenta Guerra de Troia e saudoso de Ítaca e de sua esposa Penélope, suspira pelo regresso à pátria. $\mathrm{O}$ poema relata os últimos 41 dias dos dez longos anos da viagem de retorno do esposo/herói e os seus sofrimentos em terra e no mar.

Quando finalmente regressa a Paris, depois do longo e tumultuado retorno dos campos de batalhas em que lutou ao lado de Napoleão, o coronel Chabert procura o escritório do advogado Derville em busca das armas que o ajudarão a retomar o posto perdido. A missão do herói não será fácil. Logo nas primeiras linhas Balzac informa ao seu leitor que era a quinta vez que aquele estranho personagem, ainda não nomeado, tentava se aproximar do advogado. Nas vezes anteriores, tinha sido sempre recebido com hostilidade pelos escreventes e proibido de entrar no escritório - "velho do capote" e "velho senil" eram algumas das expressões usadas para nomeá-lo.

Mas enquanto nosso herói da modernidade segue tentando, uma vez mais, se aproximar do advogado, vamos dar um pulo no tempo e ver onde se encontra o nosso herói da antiguidade. Na reta final de sua odisseia, já perto de chegar a Ítaca, Ulisses perdeu sua nau. Náufrago,

Vieira, Posfácio à Odisseia, na edição da Odisseia da Editora 34, 2013. p. 487. Por sua vez, Giambattista Vico, em sua obra Ciência Nova, considera que Homero foi um poeta idealizado, não um homem particular existente. A partir de análises filológicas e filosóficas dos poemas Ilíada e Odisseia, Vico conclui que "Homero tenha sido uma ideia, ou seja, um carácter heroico de homens gregos, enquanto esses narravam, cantando, as suas histórias" (p. 644) e que entre os dois poemas "as opiniões são tantas e tão variadas que a divergência é do espaço de quatrocentos e sessenta anos, situando$\mathrm{o}$ as mais sumamente opostas entre si, uma nos tempos da guerra de Troia, a outra cerca dos tempos de Numa" (p. 640). Cf. VICO, Giambattista. Ciência Nova, p. 640-4. 
nadando até o limite de suas forças, conseguiu chegar à ilha dos feácios, Esquéria. Lá recebeu os socorros de Nausícaa, filha do rei Alcínoo, que depois de vesti-lo e alimentá-lo o convida para visitar o palácio do rei. Mas a deusa Atena, protetora do herói, sabe que Ulisses precisa agradar os feácios se quiser receber a ajuda que precisa. Por isso, faz com que ele retome sua antiga e nobre aparência e seja recebido na corte com a hospitalidade reservada aos da sua estirpe:

\begin{abstract}
Atena infunde graça nos ombros e cabeça, o faz mais alto e forte do que o normal, para agradar a toda a gente. Queria que o respeito fosse pleno, e as honras, primaz nos múltiplos certames em que o itácio seria colocado à prova por feácios. ${ }^{8}$
\end{abstract}

Ulisses apresenta-se perante a corte dos feácios e, ainda sem revelar a sua identidade, solicita a Alcínoo um navio para o seu retorno a Ítaca, no que é prontamente atendido. O princípio da hospitalidade é caro aos gregos arcaicos, sendo a relação hóspede-anfitrião o critério mesmo da moralidade. Na Odisseia, diversos outros personagens, do ciclope Polifemo aos pretendentes, passando pelos reis, são julgados pela maneira como exercem o ideal do tratamento adequado a estranhos 9 :

${ }^{8}$ HOMERO, Odisseia. Editora 34, 2013. VII, vs. 18-23, p. 126.

${ }^{9}$ Segundo Christian Werner: "Não é de surpreender que, numa cultura arcaica, préalfabetizada, onde não havia instituições internacionais ou normas reconhecidas, o 
[...] Escutai-me, hegêmones

feácios, aconselhadores, pois direi

o que me dita o coração no peito. Ignoro

quem seja o forasteiro, se erramundo egresso

do país dos homens do sol-pôr, do sol nascente.

Roga uma escolta que lhe propicie a volta.

Como outrora, ultimemos uma esquadra. Nunca

alguém que tenha procurado meu palácio

lamentou não obter a pronta ajuda. Vamos! ${ }^{10}$

Antes de partir, o herói desfruta do lauto banquete que Alcínoo preparou em sua homenagem. Em honra ao hóspede, Demódoco, o aedo cego dos feácios, canta ao som da lira o mais audacioso estratagema da Guerra de Troia, o ardil do cavalo de madeira. Ulisses fica profundamente emocionado ao ouvir a narrativa da sua astúcia e então, envergonhado, tenta disfarçar suas lágrimas escondendo o rosto sob o manto, evitando assim expor seu pranto aos feácios. Mas, por enquanto, deixemos nosso herói lidar com suas emoções enquanto checamos se Chabert finalmente conseguiu se encontrar com o advogado.

Nas primeiras décadas do século XIX, as armas necessárias para conseguir provar qualquer coisa, seja a sua própria identidade, seja a propriedade de um imóvel, eram os documentos legais. E o advogado

comportamento correto em relação a estranhos fosse considerado obrigação sagrada [...] Essa era, com efeito, a única maneira pela qual indivíduos podiam sobreviver além dos limites de sua comunidade local." WERNER, Christian. Apresentação. In: HOMERO. Odisseia. Cosac Naify, 2014. p. 49.

${ }^{10}$ HOMERO. Odisseia. Editora 34, 2013. p. 126-7, vs. 25-33. 
era "o senhor" dessas armas. O escritório do advogado Derville, procurado por Chabert, era apenas um dos muitos que foram abertos em Paris durante a Restauração. Esse é o espaço perfeito para o entendimento da sociedade francesa daquele período, pois era nele que, sem outras testemunhas que não a do advogado, a nova classe burguesa, depois de ajudar a promover a Revolução e assustar-se com seu desenrolar, expunha os seus dramas para barganhar acordos vantajosos.

Por isso é que Chabert, depois de frustradas as tentativas anteriores de obter de sua esposa o reconhecimento de sua identidade, decide procurar Derville. Ele tinha conseguido a informação, por meio do seu antigo escritório de advocacia, de que Derville era o advogado que tinha ajudado a senhora Chabert por ocasião de sua "morte". Não demorou muito para que o velho herói percebesse que a luta que teria pela frente poderia ser tão cruel quanto aquelas travadas nos campos de batalha. $\mathrm{O}$ código que pautava as relações sociais na França burguesa não era mais a hospitalidade, como na Grécia arcaica, era o dinheiro, ou melhor, a posse dele. Pagava-se por tudo, pela documentação e até mesmo pela hospitalidade. E Chabert não possuía dinheiro algum.

Quando, finalmente, conseguiu voltar a Paris, o coronel encontrava-se numa situação terrível: sem sapatos nos pés, sem dinheiro no bolso e com as roupas em frangalhos. Sua aparência era de mendigo. Por isso, dinheiro será a primeira "arma" que o advogado irá lhe oferecer: 
Sua causa será minha causa. Breve vai aperceber-se do interesse que tomo por sua situação, que quase não tem exemplo nos fatos judiciais. Enquanto isso, vou dar-lhe um bilhete para o meu procurador, que lhe entregará, mediante recibo, cinquenta francos a cada dez dias. [...] Darei esses adiantamentos a forma de empréstimo. $\mathrm{O}$ senhor tem bens a recuperar, é rico. ${ }^{11}$

Mas estamos nos adiantando. É preciso retroceder na narrativa e ver primeiro como foi que Chabert venceu as resistências dos escreventes. Já sabemos que a aparência de "velho do capote" não ajudou muito nesse intento, pois, tão logo se depararam com aquela estranha figura, os jovens trabalhadores perceberam que dali não viria dinheiro algum. Rapidamente trataram de pensar numa forma de se livrar daquele incômodo visitante. Expulsá-lo simplesmente não tinha funcionado antes, o sujeito era persistente. Por isso, um dos praticantes tratou logo de anunciar ao coronel que o advogado só voltaria para casa de madrugada; quem sabe se, informado daquele horário impróprio, o velho desistiria.

Se o objetivo era fazer com que o coronel desistisse, o resultado foi o oposto. Animado com a perspectiva de conversar a sós com o advogado, afinal de contas durante a madrugada eram grandes as chances de que isso pudesse acontecer, o coronel surpreendeu o

${ }^{11}$ BALZAC, H. O Coronel Chabert, p. 356-7. 
primeiro praticante ao tocar a sineta cerca de uma hora da madrugada.

$\mathrm{O}$ advogado chegou um pouco depois e ficou estupefato ao entrever na penumbra o singular cliente que o esperava.

Balzac faz então uma minuciosa descrição do coronel, associando características físicas à disposição psíquica correspondente, bem ao gosto das ciências da frenologia e da fisiognomonia ${ }^{12}$, em voga na sua época. Assim, por exemplo, a ausência de calor no olhar do coronel era comparada aos degradantes sintomas pelos quais $\mathrm{o}$ idiotismo se caracterizava. Além disso, utiliza imagens que acentuam o caráter patético e fantasmagórico do herói ressuscitado:

O coronel Chabert estava tão perfeitamente imóvel quanto uma figura de cera [...] aquela imobilidade não teria sido talvez motivo de espanto se não completasse o espetáculo sobrenatural que o conjunto da personagem apresentava $[. .$.$] sua fronte,$ propositalmente oculta sob os cabelos de sua peruca lisa, dava-lhe um aspecto misterioso [...] o rosto pálido, lívido, em lâmina de faca, se me é permitido usar essa expressão vulgar, parecia morto [...] a aba do chapéu que cobria a cabeça do velho projetava um sulco negro sobre o alto do rosto. Esse efeito estranho, embora natural, fazia ressaltar, pela

${ }^{12}$ Balzac foi um entusiasta das teorias científicas do seu tempo, tanto da ciência da frenologia, do fisiologista alemão Josef Gall, segundo a qual "as protuberâncias do crânio permitem tirar conclusões acerca das disposições psíquicas do indivíduo", quanto das ideias do filósofo Lavater, inventor da fisiognomonia, isto é, "a ciência de julgar o caráter de uma pessoa pelas feições de seu rosto". Segundo Paulo Rónai, na nota de pé de página do "Prefácio à comédia humana, por Honoré de Balzac", "Balzac aplicou esses princípios em grande número de retratos de suas personagens". Cf. BALZAC, H. A Comédia Humana, v. 1, nota 24, p. 639. 
subtaneidade do contraste, as rugas brancas, as sinuosidades frias, o sentimento desbotado daquela fisionomia cadavérica. ${ }^{13}$

Recuperado do choque provocado pela visão daquele pobre homem, Derville pede que o visitante se apresente: "A quem tenho a honra de falar?" pergunta o advogado. "Ao coronel Chabert”, responde o velho. "Qual deles?”, torna a perguntar o advogado. "O que morreu em Eylau”, responde o ancião. Depois de anos de errâncias e de atribulações, período em que foi dado como morto, o herói enfim retorna. Ele está pronto para retomar a palavra e contar a sua verdade sobre os fatos passados:

Deixe-me primeiro precisar os fatos, explicar-lhe antes como eles devem ter se passado, do que como realmente se passaram. Certas circunstâncias, que só o Padre Eterno deve conhecer, obrigam-me a referir vários deles como hipóteses. ${ }^{14}$

Como estudioso e interessado nas ciências do seu tempo, provavelmente Balzac teve conhecimento das discussões no século XIX acerca da constituição da História como disciplina científica, isto é, do momento em que buscou afirmar sua cientificidade tomando por modelo as ciências físicas e naturais. Com esse objetivo, o historiador deveria descrever o passado da maneira mais racional e objetiva

\footnotetext{
${ }^{13}$ BALZAC, H. O Coronel Chabert, p. 341.

${ }^{14}$ BALZAC, H. O Coronel Chabert, p. 344.
} 
possível a partir da análise documental, mantendo distância dos relatos subjetivos.

E Chabert, ator dos fatos, só poderia produzir relatos a partir dos sentidos e da visão subjetiva. Por isso, Balzac avisa ao leitor que seu personagem não relata verdades, não descreve os fatos como eles realmente ocorreram, mas somente como podem ter ocorrido, o que significa que, quando se propõe a narrar e a louvar os seus feitos, o coronel produz apenas hipóteses.

Como são muitas as aventuras a serem narradas, deixemos os dois por um momento. Ainda é madrugada no século XIX, como também na ilha de Esquéria, onde Ulisses já deve ter secado suas lágrimas.

Antes de ter emocionado o herói itácio com sua narrativa sobre os feitos do cavalo, Demódoco havia surpreendido Ulisses com o canto sobre a sua querela com Aquiles. Por isso, impressionado com a "veracidade" do canto do aedo, Ulisses dirigiu-lhe o seguinte elogio:

Louvo-te muito acima dos demais mortais: filha de Zeus, a Musa te instruiu? Apolo? Cantas num cosmo de beleza a sina argiva, quanto fizeram, padeceram e amargaram, como se lá estiveras ou de alguém souberas. ${ }^{15}$

${ }^{15}$ HOMERO. Odisseia. Editora 34, 2013. vs. 486-491, p. 141-2. 
François Hartog descreve essa saudação de Ulisses como portadora de dois momentos diferenciados: no primeiro, o elogio convencional ao aedo inspirado, e no segundo, a surpresa com a descrição precisa da narrativa, como se Demódoco tivesse estado presente ao acontecimento, algo que o próprio Ulisses sabia ser impossível, dada a cegueira do aedo. Para Ulisses, então, a verdade da narrativa encontra-se justamente na visão das testemunhas dos fatos ou de quem ouviu os relatos diretamente delas. É o que nos afirma Hartog:

\begin{abstract}
A narrativa de Demódoco é verídica "demais", parece dizer Ulisses, para não resultar de uma visão direta das coisas. Para ele, o ator e a testemunha, esta capacidade de evocar tudo até em detalhes, sem perda e sem excesso, é a marca segura da verdade do canto. Na realidade, para a musa, ver, saber e dizer estão em pé de igualdade, são apenas uma única e mesma operação. Mas, para Ulisses, por uma curiosa inversão, é a visão humana que é tomada, pelo menos no tempo destes versos, como modelo sobre o qual medir a exatidão da visão divina. ${ }^{16}$
\end{abstract}

Alcínoo, tão logo percebe a emoção de seu convidado, pede ao aedo que silencie seu canto e ao hóspede que se apresente com sinceridade. O herói, com o famoso e convicto "Eu sou Ulisses", começa então a desfilar para o rei e seus comensais o longo rosário de suas gestas gloriosas. De acordo com Hannah Arendt, esse é o momento

${ }^{16}$ HARTOG, François. Regimes de Historicidade, p. 74. 
em que Ulisses se reconcilia com a verdade através das lágrimas da recordação. ${ }^{17}$ Podemos perceber que entre as duas narrativas a História percorreu um longo caminho: do seu nascimento na tradição, com Ulisses, ao momento em que se pretende ciência, com Chabert.

Como verdade ou como hipótese, as duas narrativas têm em comum o fascínio que despertam nos seus ouvintes/leitores. Ulisses e Chabert assumem o posto de narrador, tecendo histórias sedutoras, elaboradas numa narrativa autobiográfica. $\mathrm{O}$ resultado é uma sensação de intimidade, de intensa interação entre os heróis e o ouvinte/leitor. Assim, durante a madrugada, no palácio de Alcínoo e no escritório de Derville, os dois guerreiros desfiam maravilhosas aventuras, que incluem canibais gigantes, feiticeiras sedutoras, fantasmas e monstros marinhos, ingredientes eternos das histórias populares de todo o mundo.

Na Odisseia, Ulisses relata ao rei Alcínoo os episódios do ciclope Polifemo, as aventuras com os Lestrigões, como escapou ao canto das sereias e como, com a ajuda de Hermes, consegue fugir da ilha da feiticeira Circe. O mundo percorrido por Ulisses na sua década de errância não pertence às terras conhecidas pelos ouvintes de Homero, é uma viagem pelo imaginário, o que não significa que eles duvidassem, por exemplo, que a Guerra de Troia tivesse realmente acontecido.

${ }^{17}$ A expressão de Arendt é a seguinte: "A cena em que Ulisses escuta a estória de sua própria vida é paradigmática tanto para a História como para a Poesia; a 'reconciliação com a realidade', a catarse, que segundo Aristóteles era a própria essência da tragédia, constituía o objetivo último da História, alcançado através das lágrimas da recordação". Cf. ARENDT, H. Entre o passado e o futuro, p. 74-5. 
No século XIX, o romance de Balzac também fascina aqueles leitores acostumados, desde o século XVI, às narrativas de viagens com seus relatos de terras distantes e de mundos desconhecidos. Façamos então como os ouvintes/leitores e deixemos que Balzac/Chabert nos encante com sua imaginação:

- Senhor - disse o defunto -, talvez saiba que eu comandava um regimento de cavalaria em Eylau. Muito contribuí para o êxito da célebre carga que Murat ${ }^{18}$ fez e que decidiu a vitória. No momento em que voltávamos para o lado do imperador, depois de termos dispersados os russos, encontrei um troço de cavalaria inimiga. Precipitei-me sobre esses teimosos. Dois oficiais russos, dois verdadeiros gigantes, atacaram-me ao mesmo tempo. Um deles deu-me na cabeça uma cutilada que cortou tudo, até um gorro de seda preta que eu usava, e abriu-me profundamente o crânio. Caí do cavalo. Murat veio em meu socorro, passando por sobre mim, ele e toda a sua gente, mil e quinhentos homens apenas! ${ }^{19}$

Chabert sobrevive à passagem de mil e quinhentos homens sobre seu corpo! Feito impressionante, comparável aos feitos do herói grego. Mas desde o início dessa narrativa é exatamente o que vimos fazendo, comparando Chabert ao herói Ulisses. Afinal, do que é feito o herói? Isabela Fernandes, em artigo que discute o conceito de hybris - a transgressão dos limites humanos -, aponta o parentesco com os deuses como o elemento constituidor do herói:

\footnotetext{
${ }^{18}$ Nota do autor. Refere-se ao cunhado de Napoleão, Joachim Murat, cf. nota 18 na p. 13.

${ }^{19}$ BALZAC, H. O Coronel Chabert, p. 343-4.
} 
Todo herói grego possui ascendência divina - em algum ponto da árvore genealógica do herói existirá um deus; mas isto não o torna um deus. Como mortal, o herói será vulnerável, e vai percorrer o destino humano de erro, queda e sofrimento. [...] Situando-se a meio caminho entre o divino e o humano, o herói vai possuir uma personalidade ambígua, contraditória [...] que vai levar o herói a experimentar aventuras pontuadas de glórias e de falhas, de vitórias e fracassos. Após alcançar vitórias sobre-humanas e conquistas memoráveis, ele também está condenado a falhar em algum ponto [...] O herói será um homem poderoso e virtuoso, mas também essencialmente voltado para o descomedimento e para a transgressão dos limites impostos aos mortais pelos deuses. ${ }^{20}$

Muitas histórias míticas partem dessa perigosa colaboração entre divino e mortal. Foram muitos também os heróis que desafiaram e ofenderam os deuses, assim como foram muitos os que conquistaram sua admiração. Ulisses é exemplo das duas situações: ofendeu o deus Poseidon quando cegou seu filho, o ciclope Polifemo, e pôde sempre contar com a ajuda da deusa Atena. No século XIX, Chabert também teve o seu quinhão de ajuda dos deuses. Após ser dado como morto e jogado numa montanha de cadáveres, o coronel recupera os sentidos e só consegue se mover quando

${ }^{20}$ FERNANDES, Isabela. Criação, hybris e transgressão na mitologia heroica, p. 2. 
ao erguer as mãos, ao tatear os mortos, descobri um vazio entre minha cabeça e o lixo humano que tinha por cima de mim. [...] Ao investigar com presteza, pois não havia tempo a perder, encontrei felizmente um braço que estava solto, o braço de um Hercules!, um osso magnífico ao qual devo minha salvação. [...] Aquela alavanca, de que me servia com habilidade, proporcionava-me sempre um pouco do ar que havia entre os cadáveres que eu ia deslocando, e eu respirava parcamente. [...] Erguime apoiando os pés nos cadáveres que tinham os rins sólidos e esticando as pernas como molas. ${ }^{21}$

O braço de Hércules! Não temos aqui uma deusa formosa como Atena, mas, como os deuses sempre sabem qual a forma mais adequada para se fazerem visíveis aos humanos, um braço era exatamente do que o nosso herói precisava. Em que momento da árvore genealógica de Chabert podemos encontrar a figura divina que justifique os seus poderes sobre-humanos? Balzac, é claro, não poderia inventar um deus mitológico para ser o pai de seu herói, mas na virada do século XVIII para o XIX um personagem real ocupava esse lugar no imaginário francês: Napoleão. Não poderia haver ascendência mais "divina" para o nosso coronel:

Se eu tivesse tido parentes, nada disso, talvez, teria acontecido; mas devo confessar-lhe que sou um filho do acaso, um soldado que por patrimônio tinha a coragem, por família, o mundo, por pátria, a França,

${ }^{21}$ BALZAC, H. O Coronel Chabert, p. 345-6. 
e por único protetor Deus. Engano-me! Tinha um pai, o imperador! ${ }^{22}$

Se na Grécia antiga os deuses eram ao mesmo tempo ancestrais e tutelares das importantes famílias reais, na França do Império esse papel era desempenhado por Napoleão. Numa sociedade onde a tradição foi destronada juntamente com a nobreza, o interesse pessoal imperava como único soberano, e cabia ao imperador a decisão de nobilitar o burguês enriquecido ou um coronel que houvesse se destacado nos campos de batalha.

Ser próximo dos deuses também podia significar estar à mercê de seus caprichos e até de suas crueldades. Foi sob o efeito do poder arbitrário de Poseidon que a nau de Ulisses se separou dos demais navios aqueus, o que deu origem à sua odisseia. Em um outro momento da narrativa, Chabert relata as andanças sem fim que eram impostas aos soldados submetidos à fúria bélica e expansionista do imperador. Assim como Ulisses, Chabert percorreu o mundo, ele e seu companheiro Boutin eram

dois destroços curiosos depois de termos rolado pelo globo como rolam no oceano as pedras levadas de uma praia a outra pelas tempestades. Entre os dois tínhamos visto o Egito, a Síria, a Espanha, a Rússia, a Holanda, a Alemanha, a Itália, a Dalmácia, a

${ }^{22}$ Ibidem, p. 352. 
Inglaterra, a China, a Tartária, a Sibéria; só nos faltara ir à Índia e à América! ${ }^{23}$

Nosso herói consegue ser salvo com a ajuda do braço divino, é internado muitas vezes e foge outras tantas. Sem documentos e sem dinheiro, vaga como mendigo, sendo motivo de chacotas todas as vezes que afirmava ser o coronel Chabert, o herói da batalha de Eylau:

Durante muito tempo esses risos, essas dúvidas punham-me num estado de furor que me prejudicou e fez com que me encerrassem, por louco, em Stuttgart [...] Depois de dois anos de prisão que tive de suportar, depois de ter ouvido mil vezes meus guardas dizerem: "Aí está um pobre diabo que pensa ser o coronel Chabert" a pessoas que respondiam: "Pobre homem!", eu mesmo me convenci da impossibilidade da minha própria aventura. Torneime triste, resignado, tranquilo e renunciei a declarar ser o coronel Chabert, a fim de poder sair da prisão e voltar à França. ${ }^{24}$

A partir desse dia, astuciosamente, o coronel abre mão de seu nome. Podemos identificar, na atitude de Chabert, semelhanças com a atitude de Ulisses na ilha do ciclope Polifemo. Vamos rememorar o episódio.

${ }^{23}$ BALZAC, H. O Coronel Chabert, p. 352.

${ }^{24}$ Ibidem, p. 348. 
O encontro com o ciclope faz parte das aventuras que o próprio herói, no canto IX, narra aos feácios durante o banquete que o rei Alcínoo fez em sua homenagem. Chegando a uma ilha longínqua, não cultivada e sem cidades, Ulisses e seus companheiros se aventuraram até uma caverna, habitação primitiva de um monstro gigantesco com um único olho no meio da testa, o ciclope Polifemo, filho de Poseidon, o deus do mar. Movidos pela curiosidade, entram na caverna e aguardam a chegada do ciclope logo ao anoitecer. O problema é que Polifemo desconhece o princípio básico que rege a moral grega, a hospitalidade. Assim, o monstro não apenas aprisiona os viajantes/hóspedes como devora seis dos marinheiros que acompanhavam o herói.

Nesse episódio acontece um dos mais famosos ardis de Ulisses: quando o ciclope pergunta pelo seu nome, Ulisses não revela sua identidade verdadeira, mas se autonomeia "Ninguém"25.

${ }^{25}$ No artigo "Homero e a dialética do esclarecimento", a filósofa Jeanne-Marie Gagnebin afirma que os autores Adorno e Horkheimer cometeram um erro quando afirmaram que a astúcia de Ulisses teria sido a de escolher uma palavra foneticamente semelhante ao seu próprio nome. Segundo os autores: "Em grego trata-se de um jogo de palavras; na única palavra que se conserva separam-se o nome - Odysseus (Ulisses) - e a intenção - Ninguém. Para ouvidos modernos, Odysseus e Oudeis ainda têm um som semelhante, e é fácil imaginar que, em um dos dialetos em que se transmitiu a história do retorno a Ítaca, o nome do rei desta ilha era de fato um homófono do nome de Ninguém. O cálculo que Ulisses faz de que Polifemo, indagado por sua tribo quanto ao nome do culpado, responderia dizendo: "Ninguém" e assim ajudaria a ocultar o acontecido e a subtrair o culpado à perseguição, dá a impressão de ser uma transparente racionalização". Para Jeanne-Marie, "Adorno e Horkheimer não citam o texto corretamente. 'Ninguém' no texto homérico não é oudeis (que combina com Odysseus, o que é essencial para a problemática da negação da identidade na leitura de 143

Revista Vernáculo n. ${ }^{\circ} 39$ - primeiro semestre /2017 
[...] Ciclope, queres conhecer

meu renomado nome? Eu te direi e, em troca, receberei de ti o dom que cabe ao hóspede:

Ninguém me denomino. Minha mãe, meu pai, sócios, não há quem não me chame de ninguém. ${ }^{26}$

Depois de sua "falsa" apresentação, o herói oferece ao ciclope doses generosas do precioso vinho que conservara no navio, último sinal do mundo culto e civilizado dos homens. O ciclope fica bêbado e adormece pesadamente. Ulisses se aproveita do seu sonho para lhe furar o único olho com um tronco em brasas. O ciclope grita de dor, seus irmãos acorrem do lado de fora, mas ele só é capaz de dizer que "Ninguém" o feriu. Os outros ciclopes zombam dele e vão embora. Ulisses consegue fugir da caverna e retornar ao navio com os seus companheiros. Foi, portanto, a astúcia de Ulisses que permitiu que ele derrotasse o ciclope.

Trajano Vieira chama atenção para a inteligência do herói, capaz de manipular a linguagem: "contra o Olhicircular (Ciclope) Multifalaz (Polifemo), ele se autonomeia Outis (Ninguém)". De acordo com o tradutor, a astúcia de Ulisses está não apenas na escolha de um nome anônimo (Outis, "Ninguém") mas do sentido oculto que ninguém

ambos), mas sim outis, outro pronome grego possível. Isso significa que se há trocadilho em Homero, é um jogo entre outis (ninguém) e metis, essa inteligência ardilosa e concreta que é característica de Ulisses". Cf. GAGNEBIN, Jeanne-Marie. Homero e a dialética do esclarecimento, p. 39-40 e 43-4.

${ }^{26}$ HOMERO, Odisseia. Editora 34, 2013. Canto IX, vs. 363-367, p. 157-8. 
traz em si. ${ }^{27}$ Temos, então, dois heróis que "vivendo" em tempos distintos adotam o mesmo comportamento: Chabert/Ulisses abre mão de seu nome para fugir da prisão/caverna e retornar para Paris/Ítaca.

Vamos dar seguimento às duas narrativas e observar como se comportam os dois heróis assim que se encontram livres do perigo. Comecemos pelo herói grego. Já se afastando da praia, quando se encontra em uma distância segura, Ulisses deixa de ser Ninguém e brada outra vez o seu nome:

Ciclope, se um dos homens te indagar quem foi o responsável pelo cegamento hórrido, diz que foi Odisseu Laércio, arrasa-urbes, que habita a residência itácia. ${ }^{28}$

Aqui a questão que se coloca é: por que Ulisses, assim que se percebeu livre, precisou bradar seu nome a Polifemo? Terá sido pelo desejo de alcançar a imortalidade? Segundo Hannah Arendt, a preocupação com a grandeza, para os gregos, baseava-se no fato de que somente através da imortalidade seria possível sobreviver ao seu tempo e ser acolhido pela História:

A História acolhe em sua memória aqueles mortais que, através de feitos e palavras, se provaram dignos da natureza, e sua fama eterna significa que eles, em

${ }^{27}$ VIEIRA, T. Posfácio. In: HOMERO, Odisseia. Editora 34, 2013. p. 477.

${ }^{28}$ HOMERO, Odisseia. Editora 34, 2013. vs. 502-505, p. 162. 
que pese sua mortalidade, podem permanecer na companhia das coisas que duram para sempre. ${ }^{29}$

A filósofa Imaculada Kangussu, no texto "Divagações sobre uma questão homérica" ${ }^{30}$, apresenta algumas possíveis respostas para essa questão. Escolhemos uma que nos parece estar mais em acordo com a nossa própria reflexão:

Conforme os helenistas costumam afirmar, entre os gregos homéricos não havia conceito algum que correspondesse ao que entendemos por "consciência pessoal", então levantei uma hipótese, seria justamente por isso que Ulisses precisava do reconhecimento da besta? [...] Quero dizer, na ausência de autoconsciência, cada um teria percepção de si através da rede das relações, daí a necessidade essencial do reconhecimento? $O$ não reconhecimento implicaria, então, a perda da identidade? Em outras palavras, se o herói não afirmasse seu nome ele se tornaria de fato Ninguém, ou pior, ninguém? ${ }^{31}$

Além disso, para a autora, foi graças à decisão de Ulisses de revelar sua identidade que Polifemo pôde pedir ao pai, Poseidon, que o retorno do herói aqueu fosse o mais sofrido e longo possível. E então,

${ }^{29}$ ARENDT, H. Entre o passado e o futuro, p. 78.

${ }^{30}$ KANGUSSU, I. Divagações sobre uma questão homérica, p. 33.

${ }^{31}$ KANGUSSU, I. op. cit., p. 34. 
pelas ações de Poseidon é que o poema existe e Ulisses conquistou a imortalidade: "a origem da história é a revelação do nome. Entre ser Ninguém e ser Ulisses houve uma odisseia"32.

No século XIX, Chabert também não resistiu muito tempo à tristeza de viver sem identidade. Assim que saiu da prisão, depois de ter convencido os guardas de que falava sensatamente sobre qualquer assunto e não mais mencionava ser o herói de Eylau, o coronel sentiu necessidade de novamente "bradar" o seu nome. Para que isso acontecesse, era preciso retornar a Paris e enfrentar as ameaças dos que pretendiam ocupar o seu lugar. O que, na sociedade burguesa daquele tempo, significava abrir um processo legal. Temos, então, duas narrativas que ganham "existência" quando seus heróis assumem os riscos da revelação de seus nomes: o poema épico a Odisseia e o romance burguês $O$ coronel Chabert. ${ }^{33}$

Já encontramos algumas respostas que nos permitiram entender os "motivos" que teriam levado Ulisses a desprezar os riscos e revelar ao ciclope a sua verdadeira identidade. Vamos agora tentar entender os motivos de Chabert. Podemos encontrar nosso herói na madrugada em

\footnotetext{
${ }^{32}$ Ibidem, p. 40.

${ }^{33}$ Essa comparação nos leva a pensar no ensaio que Georg Lukács publicou no ano de 1935, com o título "O romance como epopeia burguesa". Nesse ensaio o autor trata, fundamentalmente, do gênero romanesco, abordando suas características - sejam elas formais ou conteudísticas -, sua origem, a posição que o romance assume na sociedade burguesa, as teorias estéticas acerca do gênero e sua evolução durante o processo histórico. LUKÁCS, G. apud GALLO, Renata A. G. Considerações acerca da concepção de romance nos escritos "A teoria do romance" (1914-15) e "O romance como epopeia burguesa" (1935), de Georg Lukács.
} 
que conversa com o advogado. Depois de narrar todas as agruras de seu retorno a Paris e a desilusão com a ex-esposa, o coronel, melancolicamente, profere as seguintes palavras:

Quisera não ser eu. A consciência dos meus direitos me mata. Se minha doença me tivesse tirado completamente a memória de minha existência passada, eu teria sido feliz! Ter-me-ia reengajado sob outro nome qualquer e, quem sabe?, hoje seria feld-marechal na Áustria ou na Rússia. ${ }^{34}$

Aqui temos um indício das intenções que moveram o herói na modernidade do século XIX, "a consciência dos seus direitos":

- Coronel, seu caso é excessivamente complicado disse-lhe Derville, ao sair do quarto para caminhar ao sol, em frente à casa. - A mim - disse o soldado , ele me parece perfeitamente simples. Julgaram-me morto, e eu aqui estou! Restitua-me minha mulher e minha fortuna; dê-me o posto de general ao qual tenho direito, porque fui nomeado coronel na guarda imperial na véspera da batalha de Eylau. ${ }^{35}$

Chabert tem consciência da sua própria história. Ele sabe que o passado é o garantidor de sua identidade no presente e no futuro. $\mathrm{O}$ passado em que foi conde do Império, proprietário de palacete, homem

${ }^{34}$ BALZAC, H. O Coronel Chabert, p. 348.

${ }^{35}$ Ibidem, p. 364. 
casado e respeitado socialmente. Sem esse passado, o presente se mostra insuportavelmente indeterminado: sem títulos nem palacetes e até mesmo sem casamento, ele é Ninguém. Chabert, assim como Ulisses, estaria em busca do reconhecimento, só que, dessa vez, esse reconhecimento seria mediado por mercadorias. De acordo com Kangussu,

passados séculos de história, nos quais o espírito humano desdobrou sua capacidade de autoconhecimento, a subjetividade contemporânea também é grandemente manipulada em torno do reconhecimento - agora mediado, e medido, por mercadorias. $^{36}$

Quando do seu retorno a Paris, despossuído de seu nome e identidade social, Chabert percebe-se também numa "terra selvagem". E do mesmo modo que Ulisses, somente quando novamente proferir o seu nome é que irá fixar sua identidade heroica na nova sociedade francesa. ${ }^{37}$ Por isso sua revolta com a recusa da condessa em reconhecêlo como vivo, pois sem esse reconhecimento ele continuará a ser um fantasma social, ou melhor, continuará a ser Ninguém.

\footnotetext{
${ }^{36}$ KANGUSSU, I. op. cit., p. 34.

${ }^{37}$ Segundo Lukács, enquanto o protagonista épico tem a obrigação de se tornar um herói, pois seu destino já havia sido prescrito pelos deuses, o herói romanesco, que vivia num mundo abandonado por Deus, tinha que construir o seu próprio destino heroico, através do projeto existencial que escolheu para si. LUKÁCS, G. apud GALLO, Renata A. G., op. cit., p. 42.
} 
E por que a recusa da condessa em conferir identidade àquele fantasma que retornou do mundo dos mortos? Afinal, levando adiante a leitura comparada com a Odisseia, seria lógico reconhecermos na condessa traços de Penélope, a esposa fiel. O que se passou? O que se passou foi que a ex-senhora Chabert aceitou a corte de um dos pretendentes, e a volta de seu primeiro marido significa pôr em risco essa nova união. Por isso, dissimuladamente, fingiu não reconhecê-lo:

Ela o soubera vivo, ela o tinha repelido. Depois, durante o tempo em que não mais ouvira falar nele, comprouve-se em acreditá-lo morto em Waterloo com as águias imperiais, em companhia de Boutin. Não obstante, ela concebeu o projeto de ligar o conde a si pelo mais forte dos laços, a corrente de ouro, e quis ser tão rica que sua fortuna tornasse seu segundo casamento indissolúvel, se por acaso o conde Chabert tornasse a aparecer. E ele reaparecera. ${ }^{38}$

Capacidade de dissimular, astúcia em conceber projetos, habilidade em enganar, sedução, sabedoria, sagacidade, são os epítetos que na Odisseia dizem respeito a Penélope. São os mesmos que Balzac destina a seu personagem. Senão, vejamos: ela começou como dançarina do Palais Royal, de onde saiu para se tornar condessa Chabert, esposa do herói do exército imperial. Depois da morte do marido, conseguiu triplicar sua herança graças a Napoleão, que lhe

${ }^{38}$ BALZAC, H. O Coronel Chabert, p. 375. 
restituiu a parte dos bens que cabia ao fisco pela sucessão do coronel, e graças à "falta de escrúpulos em ludibriar os pobres". Em seguida, seduzida pela ideia de entrar na sociedade aristocrática do Faubourg Saint Germain, uniu-se ao conde Ferraud, então apenas um jovem nobre falido, depois de ter seus bens tomados pela Revolução:

A Sra. Ferraud não amava no moço apenas o amante; fora seduzida também pela ideia de entrar naquela sociedade desdenhosa que, não obstante sua humilhação, dominava a corte imperial. Sua vaidade tanto como suas paixões satisfaziam-se com aquele casamento. Ia tornar-se uma mulher "comme il faut". 39

O que está em jogo aqui é a historicidade que Balzac confere ao personagem. $\mathrm{O}$ autor insere tão completamente o personagem na atmosfera de seu próprio tempo que, apesar de possuir algumas das características heroicas de Penélope, o uso que a condessa faz delas diz respeito muito mais à sociedade francesa da Restauração do que ao mito da tradição. Assim, enquanto Penélope utiliza o engodo de destecer com o objetivo de postergar uma escolha indesejada,

[...] Um deus primeiro me inspirou a armar a tela enorme em casa e então tecer brocado de perimétrica amplitude e leve.

${ }^{39}$ Ibidem, p. 372. 
[...] E consegui dobrar os corações altivos.

Mas o que entretecia na jornada, eu mesma durante a noite, à luz do archote, destecia. Três anos iludi os aqueus, os convenci $[\ldots]^{40}$

A condessa Ferraud planeja "especular com a ternura de seu primeiro marido, a fim de ganhar o processo por meio de algum ardil feminino". Portanto, na modernidade dos dezenove, a escolha do personagem teve relação com o futuro e não com a manutenção do passado. Podemos perceber, nesse vaivém entre tradição e modernidade, que o tempo como agente de transformações, conforme percebido no século XIX, imprimiu na escrita de Balzac elementos distintos daqueles encontrados no texto da tradição.

Mas é chegado o momento de voltarmos aos nossos heróis para saber o que aconteceu depois de terminadas as narrativas. Vamos primeiro ao encontro de Ulisses. Assim que terminou o banquete em que cantou a verdade de sua história, o herói foi levado pelas naus dos feácios até Ítaca. Lá chegando, precisou da ajuda da deusa Atena para se disfarçar e se aproximar do palácio sem o risco de ser reconhecido. Sua intenção era atacar de surpresa os pretendentes que tencionavam ocupar o seu lugar.

Atenção, temos aqui um dado importante: passados vinte anos, o herói precisou que Atena interviesse e o disfarçasse de ancião, pois sua aparência continuava a mesma:

${ }^{40}$ HOMERO, Odisseia. Editora 34, 2013. Canto XIX, vs. 138-140, 148-151, p. 326-7. 
E lhe responde Atena, olhos azuis: "Ao flanco teu estarei, não me distraio em tua presença, no momento da ação. Enrubrarás o solo vasto de encéfalo e de sangue de quem hoje almoça os teus pertences, pretendendo a rainha. Farei de ti um ser desconhecido a todos; tua epiderme rija eu encarquilharei nos membros fléxeis, tonsurando a coma loura; vestes andrajos, que o homem vê com ojeriza; teus olhos, hoje lúcidos, os faço baços: enojes, quando te apresentes, pretendentes, tua consorte e o próprio filho que deixaste! $!^{41}$

Com a ajuda da deusa, do filho e da esposa, Ulisses travou uma batalha sangrenta em que chacinou todos os 108 nobres que questionavam seu poder. Com a ajuda de Atena, pôs fim às lutas sangrentas e, novamente em posse de sua jovialidade, recuperou o trono, as riquezas, o palácio e Penélope, a esposa que se manteve fiel:

\section{[...] A deusa de olhos}

glaucos disse a Odisseu: "Divino Laertíade,

Odisseu multiastucioso, basta, para

a barafunda bélica homogeneizante;

não se enfurie contigo Zeus, brado-estentor!"

Nem bem falou, o herói cedeu, alegre no íntimo. ${ }^{42}$

${ }^{41}$ HOMERO, Odisseia. Editora 34, 2013. Canto XIII, vs. 392-403, p. 232-3.

${ }^{42}$ Ibidem, Canto XXIV, vs. 540-545, p. 417. 
No século XIX as coisas não se deram do mesmo modo. Depois de terminada sua narrativa, Chabert retirou-se para a periferia de Paris, bem distante do palácio em que a condessa e o conde Ferraud viviam. A passagem do tempo tinha sido cruel com o herói, sua aparência, seus valores, sua esposa, nada permanecera do modo como ele havia deixado quando partiu para lutar com Napoleão. É importante nos lembrarmos de que, enquanto Ulisses se valeu da ajuda divina para envelhecer e não ser reconhecido, Chabert se valeu da ajuda monetária para rejuvenescer e ser reconhecido.

Derville emprestou dinheiro ao coronel para que ele comprasse roupas novas e recuperasse um pouco da sua antiga aparência de cavalheiro. Assim, esperava o advogado, talvez pudesse forçar a condessa a reconhecer seu marido e assinar o acordo que permitisse ao coronel recuperar sua identidade perdida:

Os adiantamentos largamente feitos por Derville ao coronel Chabert tinham permitido a este apresentarse vestido de acordo com sua categoria social. Assim é que o defunto veio num cabriolé muito decente. Cobria-lhe o crânio uma peruca apropriada a sua fisionomia, vestia um fraque de pano azul, com roupa branca, e por baixo do colete a fita vermelha dos grandes oficiais da Legião de Honra. Ao readquirir a abastança, recuperara sua antiga elegância marcial. Mantinha-se ereto [...] Quando o 
conde desceu do carro para subir ao gabinete de Derville, saltou agilmente como o faria um rapaz. ${ }^{43}$

Mas o coronel logo percebeu que, "se conhecera a condessa do Império, via agora uma condessa da Restauração"44. Decepcionado, desistiu de lutar e recolheu-se ao hospício de Bicêtre. Um final melancólico para o sujeito da modernidade que se vê isolado entre seus semelhantes, todos tão desenraizados quanto ele. Chabert termina seus dias sem palácio e sem esposa. E, como prova do desprezo que sentia, abriu mão do título que lhe conferia identidade social: "- Nada de Chabert! Nada de Chabert! Chamo-me Jacinto - respondeu o ancião. Não sou mais um homem, sou o número 164, sétima sala". 45

\section{Referências}

ARENDT, Hannah. Entre o passado e o futuro. São Paulo: Perspectiva, 2011.

ARIGONI, Maria Inês Canedo. Illusions Perdues, de Honoré de Balzac: Jornalismo e Sociedade em Contexto. Dissertação (Mestrado) Programa de Pós-Graduação em Letras, Instituto de Letras, UFRGS, Porto Alegre, 2014.

\footnotetext{
${ }^{43}$ BALZAC, H. O Coronel Chabert, p. 381.

${ }^{44}$ Ibidem, p. 389.

${ }^{45}$ Ibid., p. 402.
} 
AUERBACH, Eric. Introdução aos Estudos Literários. São Paulo: Cosac Naify, 2015.

. Mimesis: a representação da realidade na literatura ocidental. São Paulo: Perspectiva, 2011.

BALZAC, H. A Comédia Humana. São Paulo: Editora Globo, 2012. v. 1.

. O Coronel Chabert. In: A Comédia Humana: estudos de costumes: cenas da vida privada. 3. ed. São Paulo: Globo, 2012. v. 4.

. Ilusões Perdidas. In: - A Comédia Humana: estudos de costumes: cenas da vida provinciana. São Paulo: Globo, 2013. v. 7.

BAUDELAIRE. O pintor da vida moderna. 5. ed. Lisboa: Nova Vega Limitada, 2009.

BOITANI, Piero. A sombra de Ulisses. São Paulo: Perspectiva, 2005.

CAVALCANTE, Maria I. Do romance folhetinesco às telenovelas. Revista do NIESC, Catalão-Goiás, v. 5, 2005. Disponível em: <http://www.revistas.ufg.br/index.php/Opsis/article/view/9407\#.VkSN wUs6GT4>. Acesso em: 05 out. 2015.

CARPEAUX, Otto Maria. $O$ Realismo, $O$ Naturalismo $e \quad O$ Parnasianismo por Carpeaux: o romance burguês, darwinismo e fatalismo, o romance psicológico, o século XIX. São Paulo: Leya, 2012.

CEZAR, Temístocles. Entre antigos e modernos: a escrita da história em Chateaubriand. Ensaio sobre historiografia e relatos de viagem. Almanack Braziliense, São Paulo, n. 11, p. 26-33, maio 2010. Disponível em: 
http://www.revistas.usp.br/alb/article/viewFile/11735/13510. Acesso em: 04 fev. 2017.

DAVIS, Natalie Zemon. O retorno de Martin Guerre. Rio de Janeiro: Paz e Terra, 1987.

FERNANDES, Isabela. Criação, hybris e transgressão na mitologia heroica. Disponível em: http://www.ijpr.org.br/doc/monografias/Trabalho\%20de\%20\%20Isabel a\%20Fernandes\%20\%20Criação,\%20Hýbris\%20e\%20Transgressão\%20na\%20Mitologia\% 20Heroica.pdf.. Acesso em: 20 out. 2015.

FURET, François. Dicionário Crítico da Revolução Francesa. Rio de Janeiro: Nova Fronteira, 1989.

GAGNEBIN, Jeanne-Marie. Homero e a dialética do esclarecimento. Boletim do CPA, Campinas, n. 4, jul./dez. 1997. Disponível em: http://venus.ifch.unicamp.br/cpa/boletim/boletim04/05gagnebin.pdf.. Acesso em: 04 nov. 2015.

GALlO, Renata A. G. Considerações acerca da concepção de romance nos escritos "A teoria do romance" (1914-15)e "O romance como epopeia burguesa” (1935), de Georg Lukács. Dissertação (Mestrado) - Programa de Pós-Graduação em Teoria e Crítica Literária, Unicamp, Campinas, 2012. Disponível em: http://revistas.iel.unicamp.br/index.php/seta/article/viewFile/2099/3345. . Acesso em: 07 out. 2015.

GUMBRECHT, Hans Ulrich. Modernização dos sentidos. São Paulo: Editora 34, 1998. 
HARTOG, François. Regimes de Historicidade. Belo Horizonte: Autêntica, 2013.

HOMERO. Odisseia. Tradução, posfácio e notas de Trajano Vieira. 1. ed. São Paulo: Editora 34, 2013.

Cosac Naify, 2014.

. Tradução de Christian Werner. 1. ed. São Paulo: . Rio de Janeiro: Ediouro, 2001.

KANGUSSU, Imaculada. Divagações sobre uma questão homérica. Scripta Classica on-line. Literatura, Filosofia e História na antiguidade. Belo Horizonte, n. 2, abr. 2006.

KOSELLECK, Reinhart. Estratos do tempo: estudos sobre história. Rio de Janeiro: Contraponto : Ed. PUC-Rio, 2014.

- Futuro Passado: contribuição à semântica dos tempos históricos. Rio de Janeiro: Contraponto : Ed. PUC-Rio, 2012.

LUKÁCS, G. A teoria do romance: um ensaio histórico-filosófico sobre as formas da grande épica. São Paulo: Ed. 34, 2000.

MORETTI, Franco. A cultura do romance. São Paulo: Cosac Naify, 2009.

. Romance: história e teoria. Novos Estudos, n. 85, nov. 2009.

OLIVEIRA, S. R. O século XIX e as exposições universais. Revista Brasileira de Estudos Urbanos e Regionais. Rio de Janeiro, n. 14, 2012. Disponível em: <http://unuhospedagem.com.br/revista/rbeur/index.php/shcu/article/vie wFile/1409/1382.>. Acesso em: 18 out. 2015. 
ROCHA, João Cezar de Castro. Machado de Assis: por uma poética da emulação. Rio de Janeiro: Civilização Brasileira, 2013.

SCHORSKE, Carl. A ideia de cidade no pensamento europeu: de Voltaire a Spengler. In: . Pensando com a história: indagações na passagem para o modernismo. São Paulo: Companhia das Letras, 2000.

SENNETT, Richard. O declínio do homem público: as tiranias da intimidade. São Paulo: Companhia das Letras, 1988.

STALLYBRASS, Peter. O casaco de Marx: roupas, memória, dor. Belo Horizonte: Autêntica, 2012.

TAILLANDIER, François. Balzac. São Paulo: L\&PM Pocket, 2006.

TRILLING, L. Sinceridade e autenticidade. São Paulo: É Realizações, 2014.

VICO, Giambattista. Ciência Nova. Lisboa: Fundação Calouste Gulbenkian, 2005.

Recebido em 20/06/2016, aceito para publicação em 17/02/2017 